\title{
新保険法立法の意義と課題
}

体系論的視座を中心として——

\section{村田 敏一}

\section{ロアブストラクト}

新保険法（保険法の現代化）の立法過程が着実に進行している。改めて, 立法の基本スタンスが，現行の定着化している実務に混乱を招かず，また将 来的な新商品・サービスの提供を阻害しないことに置かれるべき点につき， 確認する必要があろう。また, 今回, 相当数の導入が予定されている強行規 定の意味内容や，保険契約類型の分類と規律内容の関係等についても，実務 の混乱を避ける観点からも, 引き続き, 理論的な吟味を行う必要性があるも のと考えられる。

\section{ロキーワード}

保険法の現代化，強行規定と任意規定，保険契約類型の分類

\section{I . 前説}

平成18年 9 月 6 日，法務大臣から法制審議会に対し保険法の見直しに関す る諮問（諮問第78号）がなされてより此の方，明治期の商法制定より概ね 100年ぶりとなる保険契約法の全面改正作業は急ピッチで進められ，既に平 成19年 8 月 14 日には「保険法の見直しに関する中間試案」（以下，本稿にお いて，中間試案）および「保険法の見直しに関する中間試案の補足説明」 （以下，本稿において補足説明）が，法務省民事局参事官室より公表され，

/ 平成19年12月17日原稿受領。 
新保険法立法の意義と課題

パブリック・コメントが募られるとともに，更に法制審議会での審議が継続 され（12月現在）早ければ平成20年初にも予定される要綱案の策定・公表を 経て，平成20年度の通常国会への法案提出も展望される状況にある。従って， 本稿が公になる時点では, 既に, 国会での法案審議がスタートしている可能 性すらあり，その意味で具体的な条文を実見しない中で，標題のテーマを論 じるには些かの躊躇が覚えられる訳ではあるが，あえて当問題の重要性に鑑 み，中間試案段階での筆者の見解を㿈め，本紙上で公表しておくこととした 次第である。その意味で本稿は，先般 (平成19年 9 月 13 日), 筆者が法務省 民事局参事官室に提出した「「保険法の見直しに関する中間試案」に関する 意見募集に関する意見」につき，それを補足・敷衍する位置づけに在るもの と言える。なお，本稿では，紙幅の制約もあり，総論的・体系論的論点に比 重を置くこととし，個別具体的な立法上の論点については，中間試案公表時 点で取分け意見対立の激しかった主要論点に限定して私見を述べることとし たい。

\section{II. 総論的・体系論的論点}

総論的・体系論的論点に関しては，1 立法の基本的スタンス，2. 保険 の定義・意義と今回の立法の射程範囲，3 . 保険契約の類型論と新法の構成， 4. 任意規定と（片面的）強行規定，につき，分説する。

\section{1. 立法に関する基本姿勢（基本的スタンス）について}

今回の保険法全面改正については，近時の一連の商事法大改正の動きの中 でも，その際立った意見集約の困難性が指摘されているところである。大規 模立法行為には，己れを突き動かす実際上の差し迫った必要性（それが，実 務上のニーズであれ，理論的・体系的な問題意識からのものであれ）が無け れば一般に困難なものと言える。この点, 先行する会社法の現代化や信託法 の全面見直しにあっては, 経済環境等の変化と規律の齟龉を解決しなければ ならないという，差し迫った立法課題の顕在化，実務界のニーズが，その全 
てでは無いにせよ，少なくとも立法を推進した大きな原動力として背後に存 在したことは否定しようがないが，保険法についてこれを見ると，前述の二 法との比較感の中では，実務サイドに何としてでも今の時点で大改正を断行 しなければならないという意気込みが在ったとは到底言い難いであろう。有 体に言えば，一連の商法の現代化・現代語化の作業の中で，会社法に後続し， 商行為法の中では，保険法が相対的に我が国社会経済との密着度が高いこと から，そこに白羽の矢が立ったものとも言え，少なくとも実務上，決定的な 法改正への希求が存在していたものとは言い難い。明治32年の制定以来，殆 どその基本的骨格を変えることなく今日まで命脈を保ってきた商法典中の保 険法の規律が，この 100 年余りの保険商品の多様化・高度化や実務の進歩にと り桎梏として意識されることがあまり無かった理由は，言うまでもなく，現 行保険法の規律の性格が一解釈上は幾つかの（片面的）強行規定を含むもの の一基本的には任意規定と解され, 即ち保険者の定める約款によって, 保険 契約関係が広範囲にかつ自由度高く規律されるとともに，一方での消費者保 護は相当程度の強行法的私法規律も含む保険業法等の監督法規と, 当該監督 法規に根拠を持つ約款等基礎書類の事前認可性によって達成されて来た点に 求められる。こうした意味では，極論するならば，各監督法を通じた消費者 保護制度が維持・強化される方向性を前提とすれば，保険法の全面見直しは 「現代語化」の作業のみで足り，規律の「現代化」の必要性は否定されてし まうことともなるが，こうした見方もまた余りに非現実的なものと言える。 一たび，立法作業がスタートすれば，それを機に規律内容の合理性について の総点検が行われるべきことも当然である（仮令，任意規定であっても，そ の「標準性」につき検証する必要はある）し，また「現代語化」作業のみで， 国会に法案が持ち上げられないことも，これまた当然の理であり，その意味 で立法者にとって一たとえ実務上は差し迫った解決課題として認識されなく とも一幾つかの目玉を法案中に仕込まなければならない点も, 立法に伴うあ る種の生理的現象と言える。また，実務サイドにとり，立法に向けた誘因が 全く存在しないかと言えば，これまた否であろう。平成13年 4 月に施行され 
新保険法立法の意義と課題

た消費者契約法は当然のことながら，保険法実務にも相当のインパクトを齊 した。まず，消費者契約法10条のいわゆる約款内容に関する一般規制条項と の関係で, 多くの家計保険分野の約款条項が一応は検討の助上に上ることと なった。もとより，同法10条の規制内容についての有権解釈は，いわゆる確 認説を採用するとともに，ドイツ法とは異なり我が国では，任意規定の指導 形象機能が肯定されているものでは無いとの理解に立つ訳であり1)，また文 理解釈上も民法 1 条 2 項の信義則に反するとの要件は「かつ」要件であって 到底, 確認説以外の説を採用する余地は無い訳であるが，一方で，民法学説 にあっては, 相当程度, 創設説や指導形象機能の採用説が主張されている し ${ }^{2)}$ ，また何よりも，信義則自体が極めて抽象的な概念であることから，確 認説的理解に立つことが正当であるとしても，信義則の解釈として約款の民 商法の任意規定からの乘離が合理的なものかどうかという判断尺度が新なに ある程度は付加されるというのが，大方の見方であろう3。こうした中で， 約款を作成する保険者の実務サイドが，一もちろん基本的には杞憂に終わる ものではあろうが一新保険法に明文で現行の約款実務を肯定する条項を強行 規定あるいは任意規定として定めるように求めるのは，ごく自然な実務担当 者としての気持ちであろうし，例えば，契約成立後のモラル・リスク対処策 として約款に規定され，現実に重要な機能を果している重大事由による解除 (特別解約権) に関する立法化の要望も, このような文脈においても理解さ れよう。また，消費者契約法との関係でより深刻な課題となり得るのは，い わゆる無解約返戻金型商品・低解約返戻金型商品について，解約返戻金に関 する約款の規律と消費者契約法 9 条 1 号による過大な違約金や損害賠償額の 予約の合意を無効とする規律との関係についての理解の在り方である。この 問題は，同法10条のような一般条項の解釈を介在させないだけに，より直截

1）経済企画庁国民生活局消費行政第一課編『逐条解説消費者契約法』商事法務 研究会, 2000年, 174-177頁。

2）例えば，潮見佳男編著『消費者契約法・金融商品販売法と金融取引』，経済法 令研究会, 2001年, 88頁 (松岡久和執筆)。

3）山本豊「消費者契約法(3)」『法学教室』243号，2000年，62頁。 
的に実務に影響する可能性のある問題として立ち現れ，それだけに実務サイ ドからの，新保険法への規定化を通じて，消費者契約法との抵触による無効 の疑義を完全に払拭し去りたいという希求はより強いものとなっている。こ のように，保険者の実務サイドからは，消費者契約法との抵触回避という見 地からの立法要望がニーズとして顕在化していたものと言えよう。なお，消 費者契約法との関係では，同法11条（他の法律の適用）も論点となるが，同 条が文言上，1 項では曖昧ながらも，消費者契約法の民商法に対する優先適

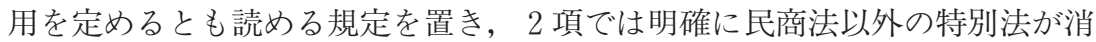

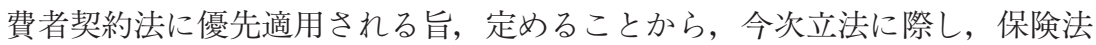
が商法典から独立し単行法化されると, 消費者契約法との抵触の疑義の在る 項目の保険法への明文規定化と相俟って，一層確実に，当該保険法実務の安 定度が増すとの見方もあるようである。しかし，この点に関しては，そもそ も法形式的に民商法典に規定するか特別法に規定するかにより，実質的には 同じ規律内容であるにも拘わらず，消費者契約法との優先適用関係が逆転す るというのは，予てより指摘されているとおり，如何にもおかしいし4)，ま たそもそも消費者契約法11条の 1 項と 2 項の規定振りの差からは， 1 項につ いては必ずしも民商法に対する一律的な消費者契約法の優先適用を規定する ものでは無く，合理的な解釈により少なくとも商法の消費者契約法に対する 優先適用の余地は許容されているものと解すべきであろう。

さて，ここで今回の立法の一つの眼目とされる，家計保険分野を中心とし た保険法への（片面的）強行規定の積極的導入による消費者保護の強化と， 保険業法による規律，取分け約款認可制を通じた消費者保護との関係につき 瞥見しておこう。EU 諸国において，約款認可性が統一的に排斥されたこと もあり（なお，米国諸州では家計保険分野においては，一般に約款認可制は 維持されている)，我が国でも，そう何時までも約款認可制は存続するもの では無いとの観測が，保険法上に強行規定を多く導入すべきとの論調の一つ

4）山下友信「消費者契約法と保険約款一不当条項規制の適用と保険約款のあり 方」『生命保険論集』No.139，2002年，10-11頁。 
新保険法立法の意義と課題

の大きな背景を成しているものと考えられる5)。しかし，我が国において， 少なくとも家計分野の保険につき，約款認可性を廃止すべきとの方向性は何 ら打ち出されていないし，またこの問題（保険業法の改正）を検討する立場 にある金融審議会において，過去そのような方向での議論がなされたことは 無いし，また12月現在，保険法改正に伴う保険業法の整備事項につき審議が なされている同審議会作業部会においても，当該事項は検討課題とはされて いないし，さらに政府の規制改革を審議する場においても公式には，当該テ 一マは取り上げられたことは無い。このように，将来的に我が国でも約款認 可制が廃止されるとの見通しには全く根拠は無く，そのような完全な仮定に 基づき，保険法の在り方（強行規定の積極的導入による約款認可制への代 替）を議論することは誤りといえよう。仮に一筆者は，消費者保護機能とし て約款事前認可制は優れており，廃止すべきではないと考えるものの一将来 約款認可制の廃止という方向性が政府として打ち出されるのであれば，その 時点で改めて保険法による規律の在り方を必要に応じ見直せば足りるものと 言えよう。

このように，保険者の実務サイドからは，主として消費者契約法との抵触 回避を意識する中で，保険法に関する立法要望が顕れてきた訳であるが，と は言え，己れは現行の約款による実務の変更を余儀なくするような立法要望 ではなく，むしろ現行実務の正当性・合理性を補強するという観点からの要 望であることは言うまでもない。そもそも新保険法の立法の在り方を検討す るに当り，それに伴い，現行の約款に基づく実務はどのような場合に，また どのような範囲で強制的に変更されるべきかについての基本スタンスを確立 しておく必要がある。既に定着している約款に基づく実務を修正・変更する には，一般に多大なシステム・事務設計等の変更に伴うコストが嵩み，取分 け生命保険契約を典型とする長期保険契約にあっては，既契約にまで遡及的

5）山下友信「保険契約法現代化に向けた課題 上」『金融財政事情』，2006年 4 月17日，32-33頁。洲崎博史「新保険法の射程と構造」『商事法務』No.1808, 2007年，3-4 頁。 
に実務変更を行うとなると，その必要費用は一層増嵩し，その結果，契約者 等へのコスト波及も生じることから，契約者等利益が侵害される蓋然性が高 い。従って，約款・実務の変更を迫るような法改正は基本的には行うべきで は無く，その改正範囲は現に苦情等が頻発し消費者保護上の問題点が顕在化 して黙過し得ない状況が生じており，かつその是正を（保険業法等他法の改 正やその適用の変更では無く）保険法の改正（強行規定化）を通じて行うこ とが最適と判断される場合（例えば，今回の改正では，損害保険契約に関す る超過保険に関する規律の変更）に限定すべきものと考えられる。では，こ のような法改正と現行約款実務維持の要請との基本的関係についての理解を 前提とした時，一方での立法の「目玉作り」というこれまた避けて通れない 要請との調和点をどこに見出すべきか，換言すれば両課題の同時達成を如何 に図るべきかが，差し迫った解決を求められる課題として立ち現れる。まず は，強行規定化等の立法の態様と約款＝実務との想定される関係変化につき， 若干のパターン分析を行ってみよう。さしあたり新保険法で任意規定とされ る範疇についての考察は捨象することとして, 同法で（片面的）強行規定と される範疇に限定して考えると，大分類としては，A．現行は保険法上に規 定がなく新たに強行規定化されるもの，B，現行は保険法上任意規定である ものが強行規定化されるもの，C．現行保険法上も強行規定と解されており 引き続き強行規定とされるもの，の 3 者が，実務（約款）の強制的見直しを 迫る可能性があり得る領域と考えられる。さらに，Aについては，A 1。強 行規定の内容が現行約款と抵触するもの，A 2 . 強行規定の内容が現行約款 内容と整合的であり特段の実務変更の必用のないもの，A 3 . 現在そうした 実務は行われておらず新規に実務構築が必要なもの, に分類可能であり，こ の中で，A 3 については，A 3 (1). 保険者が必ず新規に実務構築する必要性 があるもの，とA 3 (2). 保険者にとりその販売商品等の範囲選択により実務 構築の必要性が実質的には任意となるもの，に細分可能となる。次に B に関 しても全く同様に，B 1，B 2，B 3 （Ｂ３１１，Ｂ３（2）に分類が可能とな る。最後にCに関しては，C 1 . 現行どおりの内容を維持するもの（=約款 
新保険法立法の意義と課題

見直しの必要性は，法違反をしていない限り生じない)，C 2 . 強行規定の 内容を修正するものに分類され，さらにC 2 は，C 2 1). 全ての保険者に実 務変更を迫るものと，C 2 (2). 保険者にとり選択可能なものに細分可能とな る。まず，以上の中で， A 2, B 2, C 1 については，(少なくとも新たに 保険法の適用対象となる共済を除いては）基本的に実務変更の必然性は生じ ず，こうした領域での規律の強行規定化（または維持）については，今後新 規に開発される蓋然性がある商品やサービスの制約とならないかの検証さえ 経れば，それ程大きな問題はないものと評価されよう（こうした領域の典型 例としては，オール・オア・ナッシング主義を維持した場合の告知義務に関 する規律の強行規定化や，同じく告知義務に関する自発的申告義務から質問 への応答義務への修正がある)。次に A 1, A 3 (1), B 1, B 3 (1) C 2 (1) については，前述したとおり，コストをかけた実務変更が必要となり消費者 利益と背馳することから，余程の規律導入の切迫性が検証された場合を例外 として，単に規律内容の比較法的整合性や体系論的美学のみを理由として改 正を行うことは不適切なものと評価される（例外に該当するケースとしては 超過保険に関する規律の見直しが挙げられよう)。最後に，A 3 (2)やB 3 (2)， C 2 (2)については，両類型の中間に位置するものとして，謙抑的な立法姿勢 を維持することが望まれるとともに，代替的に実務の標準を示すという意味 での任意規定化が模索されるべき領域と言えよう。なお，上記分類の何れに も属さない改正検討事項として, 例えば生命保険契約や定額の傷害・疾病保 険契約につき金銭の支払い以外の給付を認めるかという問題があるが，この ような事項は確かに新たな実務構築を保険者に課するものではあるが，あく まで保険者の選択により，新規のニーズ対応と収益源確保の途を拓くもので あり，積極的に認めていくことが適当と考えられる。さて，このように立法 の目玉は，i 既存実務に影響しない，すなわち既存の実務と整合的な強行規 定化（例之ば告知義務に関するオール・オア・ナッシング主義の強行規定化 や，解約返戻金に関する規律の新設。特に後者は，無解約返戻金型商品・低 解約返戻金型商品につき，消費者契約法との抵触回避の観点から有効と評価 
される。），ii任意規定化による消費者ニーズへの対応（例えば，遺言による 保険金受取人の変更), iii極姶理性を欠く実務を変更するための強行規 定の見直し（例えば超過保険に関する規律の見直し），iv新規の消費者ニー ズへの積極対応（例えば生命保険契約等に関する現物・役務給付の許容）と いった i 乃至ivの各領域に求めていくことが適切と考えられる訳であるが, 必ずしも実際の立法に当たっての「目玉」として位置づけられる検討事項が こうした領域に限定されているものとは言えない（そのような例外事項の例 としては，保険金受取人等の意思による生命保険契約の存続や責任保険契約 に関する保険金からの優先的な被害の回復が指摘されよう)。そのような例 外的事項の立法化も立法政策的な諸般の事情に鑑み，一部は止むを得ないも のと考えられる訳であるが，当該立法事項については，あらゆる法技術を動 員して，可能な限り保険者・保険契約者という保険契約当事者にとっての実 務負荷の発生をミニマイズする方向での立法努力がなされるべきであろう。

\section{2 ．保険の定義・意義と今回の立法の射程範囲}

今回の立法に際して，しばしば保険（契約）につき，実質的な定義規定を 明文で設けるべきか否かという議論がなされている。「中間試案」において は，「保険」の意義につき，例えばとしながら「保険，共済その他いかなる 契約の類型であるかを問わず，発生するかどうか又は，発生の時期が不確定 な一定の事故（一定の偶然の事故）が発生する危険に備えるために，多数の 者がその危険に応じて保険料を拠出し, 事故が発生した場合にその拠出を受 けた者が金銭の支払その他の給付をし，危険への備えを実現することを内容 とする仕組み」とする案が示されつつも，法文上規定することの当否も含め， なお検討することとされていた ( $「$ 中間試案」 1 頁)。そもそも「保険」の意 義につき実質的な定義規定を置くべきかどうかという議論を行う実益は奈辺 に見出されるのか。また，そもそも，こうした議論の前提として，「実質的 な定義」とは何を意味するのかにつき確認しておく必要があろう。立法者は 現行の保険契約法に実質的なその定義を欠いているとの前提認識に立ってい 
新保険法立法の意義と課題

るものと考えられる。そのような意味での「実質的な定義」とは，機能論的 に言えば，保険法の適用範囲が，その規定振りの文理解釈から過不足なく （暗黙の書かれざる要件を観念しなくとも）導かれるような法的定義を意味 しているものと考えられる。要するに，有名契約としての保険契約につき， それに関する規律が適用される範囲を過不足なく明らかにすることに，実質 的定義につきその規定振りを腐心する意義が有るものと言える。裏を返せば， 現行の商法が有している定義らしきもの（損害保険に関する定義＝商法629 条と，生命保険に関する定義＝商法673条の和）では，全てのいわゆる保険 契約がカバーされてはいないものと考えられている訳である。そしてその意 味はさらに四つの要素に分解可能である。即ち，まずは(1)典型契約（有名契 約）でない保険契約＝傷害・疾病保険契約が現実に存在すること（保険契約 につき損害保険契約十生命保険契約とすると明らかに範疇外の保険契約類型 の存在), 次に(2)商法が規律する（営業的）商行為たる保険契約法が適用 （営利保険）あるいは準用（相互保険）されない「保険契約」類型が明らか に存在すること(いわゆる共済契約)，そして(3)現行典型契約としての「損 害保険契約」「生命保険契約」の定義それ自身も決して「過不足ない」とい う観点からは十分なものと言えないこと（傷害・疾病保険が典型契約とされ れば，やはり同様の問題が生じることとなる), 最後に(4)こうした全ての類 型の「保険契約」を統一的・包括的に定義する規定が欠如していることであ る。こうした四つの課題への対処法としては，(1)ついては，傷害・疾病保 険契約を新たに新法の中で典型契約として位置づけることで，とりあえずは， 解決可能であるし（典型契約として位置づけるということは，取りも直さず， 過不足無いものかどうかはさておくとして，何らかの定義規定は置かれるこ ととなる)，(2)に関しては，「中間試案」が提案するように「共済その他いか なる契約の類型であるかを問わず」と新法に規定することや，あるいは各制 度共済根拠法に保険法の準用規定を置くことで解決出来る（尤も後者の手法 に拠ればもし制度共済以外の共済の存在が許されるとすれば，当該共済につ いての保険法の適用関係が明確で無くなるという欠点が在る)。このように 
考えると，難問は主として(3)，(4)の領域に横たわっているものと言えよう (3)につき完璧な定義が仮に達成されたとしても，それ以外の保険契約類型 が出現すれば(4)達成出来ない)。過不足の無い包括的定義規定（実質的定 義）を置くことの意義は，当然のことながら実質的には保険契約であるにも 拘わらず，契約の法形式に細工することで保険法の適用対象となることを免

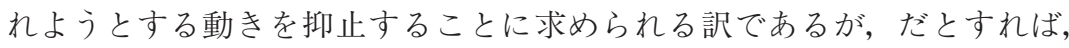
（家計保険分野を中心として）強行規定を相当数設けようとする今回の立法 の方向性に照らせば，実質的定義を置く必要性は相当差し迫っているとの見 方も一応は可能であろう。しかしながらこうした考え方に対しては，規律対 象の潜脱を防ぐという立場からも，幾つかの反論が可能となろう。まず，法 技術的に「過不足無い」定義規定を置くことは，非常に困難だということで ある。詳細に定義すればする程（その定義の要件が詳細である程），契約の 内容を細工して，その反対解釈を通じた規律の適用逃れを図るといった鼬ご つこが行われる危惧が生じてしまう懸念がある訳であり，だとすれば，むし ろ総体としての保険法が定める規律が適用されるべき契約類型こそが「保険 契約」であると観念し，裁判官に「保険契約」にあたるかどうかの判断を一 定の範囲で委ねる方が，却って規律の適用逃れ対策としては実効的との考え 方も十分成立しよう（両者の中間にある考え方として裁判官への判断のヒン トとなるような緩やかな定義を置くという考え方が在ろう）。例えば，告知 義務に関する規律につき今回，強行規定化の方向が示されているが，定義規 定との関係では，果して告知義務制度を全く排除した保険商品（いわゆる無 選択型商品）が保険法の規律の及ぶ保険なのかという問題がある（告知義務 制度に関する強行規定の性質とも相関するが，その点は後程検討する)。保 険契約の定義に関し，「危険に応じて」といった要件を挿入すると（補足説 明 6 頁)，全く危険選択を行わない商品については（年齢・性別による料率の 差異が無ければなお更のこと）保険契約の範疇から除外されてしまい，家計 保険分野では保険法の他の強行規定の適用も免れてしまう結果を齊しかねず， 果してこのような現象の発生が妥当かという問題である。換言すれば，定義 
新保険法立法の意義と課題

規定の精緻化が却って，規律の潜脱を招来しかねないというジレンマの発生 とも捉えられよう。もう一つ例を挙げると，平成17年の保険業法改正におい て，保険の定義につき，「不特定性」の要件が削除されるとともに「多数性」 の要件が緩やかではあるが導入された訳であるが，当該改正はいわゆる無認 可共済を相当程度禁圧し，消費者保護の前進を図るという文脈では威力を発 揮したものの，仮に当該改正をそのまま保険契約法改正に当て嵌めると，今 度は逆に（保険業法等の監督法の適用を受けない保険者が引き受ける契約に 事実上，限定されようが)，「多数性」の要件を欠くことを盾に保険法の適用 を免れようとする「保険者」の叢生を助長することになりかねないという逆 の形の問題が生じてしまう懸念があろう。さらに一点，少し異なる角度から この問題を考えてみよう。保険の実質的定義規定の精緻化とは，保険の実質 的機能に着目し，同じ機能の契約類型は同じ規律に服するべきという意味を 含意する訳であるが，こうした考え方を徹底すると，同一の経済的目的を達 成するための法形式 (契約類型) は一つに限定されねばならないという，こ れまた柔軟性に欠けるとともに現実とも乘離した結論を招来しかねないこと となろう。現に企業年金に関する生命保険契約と信託契約の競合・競争のよ うに同一の目的を達成するための制度（契約類型）間競争はいくらでも見ら れる訳であり，制度間の競争条件が一方的に不均衡でない以上（メリット・ デメリットが一方に偏っていない以上)，こうした競争の発生が消費者利益 に資する局面があることも肯定されよう。こうした見地から保険契約といわ ゆる保険デリバティブの関係につき，保険の定義規定に関する文脈で考察す ると ${ }^{6)}$ ，両者はリスク移転を目的とする意味では共通の機能を有しているが， 偶然な事由の発生による損害を垻補するか，損害発生の有無を問わず約定さ れた金銭の支払いをするかで，明確に区別される（境界の存在）一方で，整 理の方向としてはモラル・ハザードのないリスクに関する保険については利

6）共済に関しては，保険契約とその実質を差別化する要因は全く観念され得ず， その意味で異なる法形式を採ることによる制度間競争的なメリットは見出せな い。 
得禁止原則による制約を課す必要はなく（賭博禁止による限界のみを考える ことで足る)，保険デリバティブについてはモラル・ハザードの伴うものは基 本的に認めるべきではない（裏を返せばそうした類型についてはモラル・八 ザード抑止のためのメカニズムを装備する保険契約としてしか認めるべきで ない）との考え方が有力に唱えられている77。この考え方に依拠すれば，天 候や天災の発生等モラル・ハザードと基本的に無縁の領域に保険デリバティ ブは限定され（それ以外は実質的に保険契約として家計保険であれば保険法 の強行規定の支配下に置かれる)，一方の保険契約はモラル・八ザードの在 るものと, 無いもの（例えば興行中止保険, 生存保険）の双方を包含するこ ととなる（後者の領域では保険とデリバティブは競合する）。こうした考え 方は，結論的に，極めて妥当なものと思われるが，とすれば，仮に保険契約 の定義規定の構成要素として余りに厳格にモラル・ハザード排除の要請に直

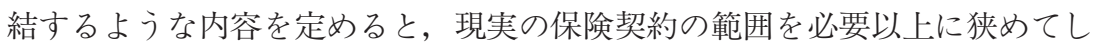
まうし，一方でそうした構成要因を全く規定しないと，今度は逆に保険の排 他的領域であるモラル・ハザードの存在する類型につきデリバティブ契約の 成立を容認してしまうというジレンマに陥ってしまう。結局のところこうし たジレンマの発生は保険契約につき厳密な定義規定を置くべきとの考えに起 因している面もあり，余り厳格な定義規定を置くことは放擲し，むしろ保険 契約法の定めるモラル関係の諸規律に照らし，裁判官がある程度，柔軟に保 険契約法の妥当範囲を判断するという考え方の方が，潜脱防止という意味で も，却って一日の長を有するように考えられよj8)。

7）山下友信「保険・保険デリバティブ・賭博—リスク移転取引のボーダー」『融 ける境 超える法(3)市場と組織』東京大学出版会，2005年，244-246頁。

8）ただし，強行規定の潜脱抑止という観点からは，デリバティブ契約の殆どが， プロ対プロの契約としてそもそも強行規定の適用除外になるものと考えられる し，また業規制として損害保険会社がデリバティブ契約の当事者となることも 一定の範囲で許容されている以上，議論の実益が生じる領域は相当程度，限定 されることとなる。 
新保険法立法の意義と課題

\section{3 ．保険契約の類型論と 新法の構成}

新法と保険契約の類型論の関係については，新たに典型契約化が予定され ている傷害・疾病保険契約をどう位置づけ，その規律内容を（実損填補型， 定額型毎に）いかなるものとすべきかという点に議論が集中している観があ る。そもそも，保険契約の類型論を行う実益につき確認すると，それは，多 種多様なヴァリエーションを有する保険契約につき，適用される規律内容群 の共通性＝契約の典型性の観点から大括りにすることにより，規範検索の容 易性・利便性と立法経済学的な効率性の双方を達成することに求められるべ きと言える。こうした観点からは，何も保険契約の類型化は損害（実損填 補）保険，（定額）生命保険，傷害・疾病保険という切り口を用いることが唯 一の解とは考えられず，例えば積極保険か消極保険か，責任保険かそれ以外 の保険 ${ }^{9)}$ か，海上保険か陸上保険かといった様及な類別法が想定されること となる。このように, 損害, 生命, 傷害・疾病という分類法も相対化される べきものではあるが，さりとて，現行商法の分類（二分法）や保険業法に基 づく分類（三分法）と懸け離れた分類を新法で導入することも，これまた実 務に無用の混乱を惹起させかねないものとして，到底，歓迎されないであろ う。そこで損害，生命，傷害・疾病という基本的な土俵の中で，知恵を競う ことが適切との結論に至る。この問題については，損害てん補方式と定額給 付方式をあわせ広く傷害・疾病保険と捉える(1)のアプローチと，「中間試案」 の採る損害てん補方式のものは損害保険契約に吸収し，定額給付方式のもの のみを固有の傷害・疾病保険契約類型とする(2)のアプローチと対蹠し，両構 成の得失につき検討がなされてきた ${ }^{10)}$ 。そうした中で，比較法的観点や学説 を踏まえ，(1)のアプローチを支持する見解が顕著なものと思われるが，しか し注意すべきは，「中間試案」は必ずしも法律の出来上がりの形（構成）ま

9）責任保険については，重複保険，超過保険，保険代位，保険金からの優先的 な被害の回復等の諸場面につき際立った適用規律の特異性を有する。

10）洲崎博史「新保険法の射程と構造」補足「日本私法学会第七十一回大会シン ポジウム・保険法改正」 
で視野に入れた案を提示しているものではないという点である。即ち「中間 試案」では，単に仮に定額の傷害・疾病保険を別出しした場合にどの程度， 定額生命保険の規律との相違が生じるかにつき確認作業を行ったに過ぎない ものとも評価し得，その結果，基本的な相違点が免責事由に関する重過失免 責の有無に止まることが（予想どおり）検証されたに過ぎないものとも考之 られる。とすれば，実はアプローチは(1)(2)に限定されず，実はより実効的と も評価し得る第三のアプローチが浮上することとなる。即ち，定額構成にせ よ，実損填補構成にせよ，およそ傷害・疾病保険契約に適用されるべき規律 が，各々，生命保険契約あるいは（物保険としての）損害保険契約の規律内 容と大きくは相違せず，かつ僅かではあるものの相違点は在る以上，結局の ところ傷害・疾病保険を第三の契約類型として，別出し規定化する必要性・ 必然性は乏しく，保険契約の大類型としては実損填補保険と定額人保険とい う二分法を（人に関する実損填補保険を有名契約化するという点等で若干， 修正しつつ）維持し，各々（二大類型毎）の箇所で必要な範囲で傷害・疾病 保険についての特則を設けるという手法が最も, 簡明かつ立法経済学的にも 効率的な構成と考えられよう。なお，考えられる特則としては，前者（実損 塡補類型）については，保険金受取人等の意思による保険契約の存続や被保 険者の意思による契約関係からの離脱が想定されよう ${ }^{11)}$ 。後者についての特 則が免責に関する重過失の取扱いに見出される点は前述した。

\section{4 ．任意規定と（片面的）強行規定}

保険契約法への積極的な強行規定（片面的強行規定を含む。以下，同じ） 導入による消費者保護の前進は，しばしば今回の立法の一つの眼目とされる。 そして，この問題に関しては，強行法規の適用対象となる保険契約の類型

11）保険金受取人等の意思による保険契約の存続については，契約者の地位の変 更は伴わず，単に保険関係者からの一定の金額の支払いの効果として差押等を 免れるものと構成すれば，被保険者と受取人の地位が未分化の実損填補型の傷 害・疾病保険についても当該制度の適用が容易となる。 
新保険法立法の意義と課題

(家計保険と企業保険の線引き問題) や，時効に関する規律の性格（絶対的 強行規定か片面的強行規定か）に焦点を当てた議論展開がなされてきたよう に思われる。勿論，こうした問題も重要なものの，併せて「中間試案」が提 言する強行規定が，必ずしも法的に全く同一の効果等を含意せず，相当，多 様な趣旨の規律内容を包含している点を踏まえた，そもそもの強行規定化の (単一ではない) 意義を吟味することも重要と考えられる（前提として，任 意規定と強行規定の適切な仕訳けが重要な点は，言を要しない) 12)。「中間 試案」で強行規定化の方向性が示された規律をざっと見渡してみると，(1)損 害保険契約の目的（被保険利益）(2)危険に関する告知（告知義務）に関する 諸規律(3)遡及保険に関する規律(4)契約の無効・取消しによる保険料の返還に 関する規律(5)危険の増加・危険の減少に関する諸規律6)超過保険に関する規 律(7)評価済保険に関する規律の一部8保険金の支払時期に関する規律の一部 (9)保険金請求権の消滅時効に関する規律(10)損害発生後の保険の目的物の減失 に関する規律11)重大事由による解除（特別解約権）12保険者の破産に関する 規律13他人を被保険者とする保険契約についての被保険者同意に関する規律 (14)被保険者の意思による契約関係からの離脱に関する規律(15)保険金受取人等 の意思による保険契約の存続に関する規律16保険料積立金等の支払に関する 規律の以上 16 項目が挙げられる。なお，(7)ににいては当該規律の一部分の みを強行規定とする点で，また(14)15については，各々強行規定とは表記され ず「これに反する約定で被保険者に不利なものは無効とする」あるいは「こ れに反する約定で一定の者に不利なものは無効とする」という規律が提案さ れている点が注目されるが，後者については契約当事者以外 (契約関係者) が有利・不利判断の客体となるため，（強行規定とは呼ばず）こうした表現 を採ったものと考えられる。さらに17責任保険に関する保険金からの優先的

12）立法者も強行規定の多義性について一定の問題意識を有していることは，例 えば「中間試案」19頁で，「片面的強行規定とは，‥基本的にこれに反する約 定で…に不利なものが無効とされる規定をいうが，その意味については個々の 規律ごとに検討する必要がある。」とされることから窺われる。しかし，その 意味が多義的であるとして，どのように条文上の書分けを行えるのであろうか。 
な被害の回復に関する規律については，その性格につきなお検討するものと されている。さて，こうした諸規律をさしあたりの対象として，その意味を 分析してみよう。まず(7)(8のようにある契約条項の一部のみが強行規定とさ れる場合であるが，その意味にはある条項（例えば評価済保険）の約款での 採用自体は任意なものの，一旦採用したらその内容は強行規定とされるケー ス（7)）と，保険金の支払時期に関し期限の定めの有無等により強行規定か 否かを使い分けるケースがあり，その両者間でも意味が異なるものと考えら れる。まず後者については，一つの規律に関し一方の選択肢を選ぶと任意規 定となり，他の一方を選択すると強行規定と位置付けられることとなり，明 らかに整合性を欠く規律設計のように評価される ${ }^{13)}$ 。次に前者であるが，こ のような制度導入は任意であるが導入した以上強行規定の規律下に入るとい う規定振りの存在を前提に，それを反対解釈すると，例えば告知義務に関す る規律のように制度全体が強行規定とされている場合，果してその制度自体 を排除することは可能かどうかという疑義が顕在化してくることとなる。裏 を返せば，制度全体についての強行規定化が提言されている例えば告知義務 制度に関しては，当該制度自体を約款で全面的に排除することが可能かとい う問題とも等置され得る。告知義務の問題は，保険そのものの実質的定義の 在り方とも絡む問題であるが，おそらく立法者は告知義務制度の無い「保険 契約」(無選択型保険）も保険契約の範疇内のものとして容認しているよう にも思われ，であるならば，結局，制度導入は任意だがその規律内容は強行 規定であるといった規定振りは，反対解釈を通じた無用の混乱を招きかねな いものとして，基本的に回避されるべきこととなろう。最後に任意規定の性 格につき付言すると，現在，殆どの生命保険会社が 3 年程度の自殺免責期間 を約款で定める中，「中間試案」は当該免責期間につき，(任意規定として） 全期間免責とすることを提言している。とすれば，任意規定の性格の理解の

13）因みに，保険金の支払時期に関する規律内容は，中間試案での提案の中でも 最もその具体的規律内容のイメージし難いものである。実務の安定化の観点か らより明瞭な規律内容とすることが求められよう。 
新保険法立法の意義と課題

在り方としては，実務のあるべき標準を示すという機能は後退し，約款に規 定なき場合それを補充するという機能に重心が置かれているとの理解が優位 に立つこととなろう（任意規定の指導形象機能の否定）。自殺につき全期間 免責とすることは，実は，任意規定としても，片面的強行規定と位置づけて も，全く同様の法的効果を招来する。一方，中間試案では任意規定とされた 請求権代位については, その後, 片面的強行規定とする方向での検討が進め られているが，この場合は，差額説以外の約款（比例説や絶対説）を無効な ものとするという効果を有する点で，片面的強行規定化は実務上も大きなイ ンパクトを与えるものと評価されよう。

\section{III. 各論}

「中間試案」が $\mathrm{A}$ 案・B案を対置する二つの項目に関しては，まず「告知 義務違反による解除の効果」についてはA案（オール・オア・ナッシング主 義）が妥当である。その理由としては，実務上・裁判規範上，故意と重過失 の弁別は困難であり，その差異により効果を異にすることは適切でないこと， $\mathrm{B}$ 案（プロ・ラタ主義）の場合，訴訟上の立証活動を通じ引受基準が周知化 されることに伴うモラル・リスクの助長が懸念されること等が指摘されよう。 次に「生前の意思表示による保険金受取人の変更」に関しては，A案が妥当 である。理由としては, 保険者を唯一の意思表示 (単独行為) の相手方とし て対抗要件と効力要件を一致させることが，契約者の常識にも合致し，実務 の安定化，紛議の回避に資することが挙げられる。

実務上のニーズは些少であるにも拘わらず，いわゆる「立法の目玉」とさ れる事項としては，生命保険領域では，被保険者の意思による契約関係から の離脱や，保険金受取人等の意思による保険契約の存続といった項目がそれ に該当しよう。いずれについても，実務負荷を極力軽減し，かつ我が国の契 約法体系との整合性を確保するための立法努力が必要であり，前者について は同意の撤回という構成ではなく，被保険者から契約者への解約請求という 構成を採ることが，また後者については，契約者を変更させることなく一定 
保険学雑誌 第 600 号

の者が一定の金額を支払うことで差止等を免れるものと構成することが妥当 であろう。

(筆者は立命館大学法務研究科教授) 